\title{
POLITIK NEgARA DALAM PENGUPAHAN BURUH DI INDONESIA
}

\author{
M. Ghufron \\ Fakultas Syariah IAIN Sunan Ampel Surabaya
}

\begin{abstract}
Abstak: Indonesia, sebuah negara yang sistem ekonominya terhegemoni oleh kapitalisme, kebijakan perindustriannya, lebih khusus lagi tentang sistem perburuhannya, di set up sebagai bagian dari sistem produksi dengan metafora mesin. Upah yang diberikan kepada buruh dianggap sebagai cost (biaya) yang sepadan dengan produktivitas yang dihasilkan. Bahkan semakin rendah upah semakin baik dimata pengusaha, sebaliknya bila upah terus menggelembung, maka akan mengurangi laba perusahaan. Pemerintah sebenarnya menetapkan kebijakan pengupahan yang melindungi pekerja/buruh dengan menggunakan standar upah minimum berdasarkan kebutuhan hidup layak dan dengan memperhatikan produktivitas dan pertumbuhan ekonomi. Akan tetapi, upah buruh yang ditetapkan dengan Upah Minimum Kabupaten/Kota (UMK) hanya untuk memenuhi Kebutuhan Hidup Minimal (KHM), bukan pada Kebutuhan Hidup Layak (KHL), sehingga seluruh potensinya habis untuk opportunity cost, tanpa pernah bisa menikmati economic rent. Hukum Islam menjelaskan bahwa pada dasarnya upah (ujrah) adalah salah satu bentuk kompensasi yang besarnya ditentukan oleh jasa atau nilai kerja (produktivitas) itu sendiri, bukan ditentukan oleh tenaga (ain al- 'Ama) yang dicurahkan oleh seorang pekerja, maupun harga produk yang dihasilkan oleh seorang pekerja. Bahkan besaran upah hendaknya juga dikaitkan dengan hak dasar untuk hidup (hifz al-nafs) secara layak. Upah dalam sistem ekonomi Islam terbagi menjadi dua macam, yaitu al-Ajr al-Musamma, dan al-Ajr al-Mithli. al-Ajr al-Musamma adalah upah yang sebutkan pada waktu akad dengan ada unsur kerelaan dari kedua belah pihak sedangkan al-Ajr al-al-Misthli adalah upah pengganti ketika dalam keadaan tidak diketahui atau ada paksaan atau penipuan. Kedua macam upah ini dalam pelaksanaannya terdapat ketentuanketentuan yang harus dipenuhi disaat berlangsungnya proses pengupahan. Di antaranya, seorang buruh haruslah dijelaskan bentuk kerjanya (job description), batas waktunya (timing), besar gaji/upahnya (take home pay), serta berapa besar tenaga /ketrampilan (skill) harus dikeluarkan.
\end{abstract}


Kata Kunci: Upah minimum, produktivitas, kebutuhan hidup layak

\section{Pendahuluan}

Dewasa ini berbagai persoalan perindustrian di berbagai negara termasuk di Indonesia dikendalikan oleh sistem ekonomi kapitalisme. Sistem kapitalisme diasumsikan cenderung mengeksploitasi kaum buruh, karena di dalam sistem ini buruh diperas tenaganya untuk menghasilkan apa yang disebut sebagai surplus value. Nilai lebih itu tidak kembali kepada buruh; melainkan kepada pihak majikan (kapiltalis). Buruh hanya menerima upah tertentu dari majikan, dan upah tersebut tidak sama sekali memperesentasikan pembagian keuntungan dari surplus value yang diperoleh suatu perusahaan. ${ }^{1}$ Hal itu, karena buruh dianggap sebagai salah satu komponen modal produksi, sama dengan komponen lainnya yang bersifat materi, sehingga para pemodal akan senantiasa menekan gaji buruh serendahrendahnya. $^{2}$

Dalam konteks keindonesian, kehadiran UU No. 13 Tahun 2003 merupakan skenario besar Pemerintah untuk mengatur hubungan industrial antara buruh, pengusaha dan pemerintah khususnya masalah pengupahan buruh. Di atas kertas, nampak bahwa ketentuan pasal-pasal dalam UU No. 13 Tahun 2003 diarahkan kepada pencapaian kebutuhan hidup layak dan kesejahteran buruh. Upah Minimum Regional, terus mengalami kenaikan sesuai dengan perkembangan daya beli masyarakat. Namun, prosentase kenaikan UMR tersebut tidak memiliki korelasi kuat dengan peningkatan kebutuhan buruh dan masyarakat. Upah buruh tersebut hanya cukup untuk memenuhi Kebutuhan Hidup Minimal (KHM), bukan pada Kebutuhan Hidup Layak (KHL), sehingga seluruh potensinya habis untuk opportunity cost, tanpa pernah bisa menikmati economic rent.

\footnotetext{
' M. Umer Chapra, Islam and economic development (IIIT: Islamabad, 1993), 21; Erich Fronm, Konsep manusia menurut max, ter.Agus Prihantara (Yogyakarta: Pustaka Pelajar, 2002), 123; Semaoen, Penuntun kaum buruh (Yogyakarya: Jendela, 2000), I-22.

${ }^{2}$ Akram, An Introduction to Islamic Economics, (Pakistan: IITH, I994), 8.
} 


\section{Dinamika Politik Pengupahan Buruh di Indonesia}

Pada masa awal kemerdekaan, hubungan industrial nampak diwarnai oleh pergolakan politik. Pasang surut kondisi buruh berubah bersama dengan perubahan di tingkat kebijakan ekonomi yang dijadikan mainstream oleh Pemerintahan Orde Lama (19451965). Kebijakan ekonomi diarahkan untuk mengupayakan redisbusi pendapatan dan kekayaan dari pertumbuhan ekonomi. Kebijakan Soekarno diwarnai dengan semangat nasionalisme melawan Amerika Serikat dan Eropa Barat. Selama bertahuntahun awal pemerintahannya, Soekarno banyak memberi dukungan kepada serikat buruh dan mengambil sikap pro buruh. Hal ini dapat disaksikan dari dikeluarkannya regulasi-regulasi perlindungan buruh serta jaminan terhadap hak berorganisasi. ${ }^{3}$

Setelah Orde Lama runtuh kebijakan ekonomi Indonesia mulai beralih dari sentralisme dan perhatian pada redistribusi pendapatan kepada ekonomi model pembangunan (development). Di bawah kendali Soeharto kebijakan perekonomian nasional disandarkan pada usaha swasta baik domestik maupun asing sesuai dengan prinsip-prinsip yang mengatur bekerjanya mekanisme pasar. ${ }^{4}$ Sayangnya, peraturan yang ada lebih mengacu pada stabilitas, sehingga nasib buruh tetap berada pada posisi inverior. ${ }^{5}$

Pada Era Reformasi, serikat buruh tumbuh dengan subur sesuai dengan aspirasi dan tuntutan terhadap pembebasan. Hal tersebut merupakan konsekwensi diratifikasinya ILO tahun 1998 tentang kekuasan berserikat dan perlindungan berorganisasi. ${ }^{6}$

Namun di pihak perusahaan, para pengusaha tidak dapat segera memenuhi standar perburuhan yang baru, di samping

3 Susetiawan, Konflik Sosial: Kajian Sosiologis Relasi Buruh Perusahaan dan Negara di Indonesia (Yogyakarta: Pustaka Pelajar, 2000), 73.

${ }^{4}$ Umnia Labiba, Wahyu Pembebasan, Relasi Buruh -Majikan (Yogyakarta: PT.Pustaka Alif, 2004), 60.

${ }^{5}$ Eggi Sudjana, Bayarlah sebelum Keringatnya Mengering ( Jakarta: PPMI, 2000), 23-25 ; Agung Widarti, "Buruh di Sektor Industri dalam Perdagangan Global". Makalah saresehan Nasional dan konggres forum masyarakat industri ( formasi), Semarang 27 maret 1997.

${ }^{6}$ Sutanto, Prospektif Tenaga kerja., 3 
karena pertumbuhan ekonomi yang rendah, juga karena mereka menghadapi sejumlah pilihan sulit, terutama berkaitan dengan pengeluaran sejumlah biaya 'siluman', yang tidak berhubungan dengan proses produksi. Selain itu persediaan tenaga kerja yang berlimpah juga menjadi salah satu pertimbangan pengusaha untuk tidak segera merespon tuntutan pekerja yang ada. Sebaliknya, sejumlah pekerja mengalami pemotongan gaji dan sejumlah besar lainnya tela mengalami Pemutusan Hubungan Kerja (PHK) massal di banyak perusahaan. Diperkirakan 13 juta manusia jadi pengangguran dari sektor formal (Perusahaan). ${ }^{7}$

\section{Pengertian dan Asas - Asas Pengupahan}

\section{Pengertian Upah}

Menurut Dewan Penelitian Pengupahan Nasional: Upah adalah suatu penerimaan sebagai imbalan dari pemberi kepada penerima kerja untuk suatu pekerjaan atau jasa yang telah dan akan dilakukan, berfungsi sebagai jaminan kelangsungan hidup yang layak bagi kemanusiaan dan produksi, dinyatakan atau dinilai dalam bentuk uang yang ditetapkan menurut suatu persetujuan, undang-undang dan peraturan dan dibayarkan atas dasar suatu perjanjian kerja antara pemberi dan penerima kerja. ${ }^{8}$

\section{Asas-asas Pengupahan}

Berdasarkan perundang-undangan ketengakerjaan tentang asas pengupahan dapat dirinci sebagai berikut:

a) Hak menerima upah timbul pada saat adanya hubungan kerja dan berakhir pada saat hubungan kerja putus (Pasal 2 Peraturan Pemerintah No. 8 Tahun 1981 tentang perlindungan Upah).

b) Pengusaha tidak boleh mengadakan diskriminasi upah bagi buruh laki-laki dan wanita untuk jenis pekerjaan yang sama

\footnotetext{
${ }^{7}$ Eggi Sudjana, Bayarlah sebelum keringatnya mengering, ( Jakarta: PPMI, 2000),7

8 Ahmad S. Ruky, Manajemen Penggajian dan Pengupahan Karyawan Perusahaan. (Jakarta: Pustaka Utama Gramedia, 200 I), 7; lihat juga Pasal I angka 30 UU No. I3 Tahun 2003
} 
(Pasal 3 Peraturan Pemerintah No. 8 Tahun 1981 tentang Perlindungan Upah).

c) Upah tidak dibayar apabila buruh tidak melakukan pekerjaan atau disebut asas no work no pay (Pasal 93 ayat (1) UU No. 13 Tahun 2003 tentang ketenagakerjaan). Asas tersebut dikecualikan bagi buruh yang tidak melakukan pekerjaan karena beberapa hal sebagaimana diatur dalam Pasal 93 ayat (2), ayat (3), dan ayat (4) UU No. 13 Tahun 2003 tentang ketenagakerjaan, sehingga pengusaha wajib membayar upah kepada buruh secara proposional berdasarkan jenis-jenis sebab masing-masing.

d) Pengusaha dilarang membayar upah lebih rendah dari ketentuan upah minimum (Pasal 90 ayat (1) UU No.13 Tahun 2003 tentang ketenagakerjaan).

e) Komponen upah terdiri dari upah pokok dan tunjangan tetap, dengan formulai upah pokok minimal $75 \%$ dari jumlah upah pokok dan tunjangan tetap (Pasal 94 UU No. 13 Tahun 2003 tentang ketenagakerjaan).

f) Pelanggaran yang dilakukan oleh buruh karena kesengajaan atau kelalaian dapat dikenakan denda (pasal 95 ayat (1) UU No. 13 Tahun 2003 tentang ketenagakerjaan).

g) Pengusaha yang karena kesengajaan atau kelalaiannya mengakibatkan keterlambatan pembayaran upah, dikenakan denda sesuai dengan persentase tertentu dari upah buruh (Pasal 95 ayat (2) UU No. 13 Tahun 2003 tentang ketenagakerjaan).

h) Dalam hal perusahaan dinyatakan pailit atau dilikuidasi berdasarkan peraturan perundang-undangan yang berlaku, maka upah dan hak-hak lainnya dari buruh merupakan utang yang didahulukan pembayarannya ( Pasal 95 ayat (4) UU No. 13 Tahun 2003 tentang ketenagakerjaan). Dalam Pasal 90 ayat (2) UU No. 13 tahun 2003 disebutkan bahwa : bagi pengusaha yang tidak mampu bayar upah minimum sebagaimana dimaksud dalam pasal 89 UU No. 13 tahun 2003 dapat 
dilakukan penangguhan. Adapun tata cara penangguhannya diatur sedemikian rupa dalam Keputusan Menteri Tenaga Kerja dan Transmigrasi No. KEP-231/MEN/2003.

i) Tuntutan pembayaran upah buruh dan segala pembayaran yang timbul dari hubungan kerja menjadi kedaluwarsa setelah melampaui jangka waktu 2 (dua) tahun sejak timbulnya hak (Pasal 96 UU No.13 Tahun 2003).

\section{Kebijakan Pengupahan Buruh di Indonesia}

Kebijakan pengupah ini ditempuh pemerintah dalam rangka memberikan perlindungan kepada buruh.

1. Upah Minimum

Kebijakan upah minimum dilakukan oleh pemerintah sejak akhir tahun 1980-an. Kebijakan ini dituangkan ke dalam beberapa perundang-undangan, seperti Peraturan Menteri Tenaga Kerja No. PER-01/MEN/1999 tentang upah minimum, yang kemudian disempurnakan dengan Keputusan Menteri Tenaga Kerja dan Transmigrasi No. KEP-226/MEN/2000 dan peraturan Menteri Tenaga Kerja dan Transmigrasi No.PER-17/MEN/VII/2005. Dalam Pasal 88 sampai dengan pasal 90 UU. No. 13 Tahun 2003 secara eksplisit semakin memperkuat pengaturan Upah Minimum.

Pengertian upah minimum menurut pasal 1 angka 1 Peraturan Menteri Tenaga Kerja No. PER-01/MEN/1999 adalah upah bulan terendah yang terdiri dari upah pokok termasuk tunjangan tetap. Dalam praktiknya masih sering bermasalah khususnya pada sektor industri padat karya, penafsiran terhadap fungsi upah minimum cenderung merugikan para buruh yang mempunyai masa kerja lebih dari satu tahun, telah berkeluarga, serta memiliki jabatan tertentu di semua level. Para buruh tersebut masih menerima upah yang besarnya sama dengan upah minimum. Begitu juga terhadap buruh yang mempunyai keahlian tertentu atau yang berprestasi, tidak memiliki perbedaan upah 
secara nyata jika dibandingkan dengan upah rata-rata buruh pada umumnya. ${ }^{9}$

\section{Upah Kerja Lembur}

Upah kerja lembur merupakan kewajiban pengusaha untuk membayarkannya kepada buruh yang telah melebihi ketentuan waktu kerja yang telah disepakati. Berdasarkan Pasal 1 angka 1 Keputusan menteri Tenaga Kerja dan Transmigrasi No. KEP102/MEN/VI/2004, pengertian waktu kerja lembur adalah waktu kerja yang melebihi 7 (tujuh) jam 1 (satu) hari dan 40 (empat puluh) jam 1 (satu) minggu untuk 6 (enam) hari kerja dalam 1 (satu) minggu; atau 8 (delapan) jam 1 (satu) hari dan 40 (empat puluh) jam 1 (satu) minggu untuk 5 (lima) hari kerja dalam 1(satu) minggu, atau waktu kerja pada hari istirahat mingguan dan atau pada hari libur resmi yang ditetapkan pemerintah.

Adapun Jenis dan sifat pekerjaan yang dijalankan secara terus menerus seperti pekerjaan di bidang pelayanan kesehatan dan transportasi, dimana pengusaha memperkerjakan pekerja/buruh pada hari-hari libur resmi, wajib membayar upah kerja lembur. Tetapi, bagi pekerja/buruh yang termasuk dalam golongan jabatan tertentu, tidak berhak atas upah kerja lembur, dengan ketentuan mendapat upah yang lebih tinggi. Yang termasuk golongan jabatan tertentu adalah pekerja/buruh yang memiliki tanggungjawab sebagai pemikir, perencana, pelaksana dan pengendali jalannya perusahaan yang waktu kerjanya tidak dapat dibatasi menurut waktu kerja yang ditetapkan perusahaan sesuai dengan perundang-undangan.

\section{Upah Tidak Masuk Kerja Karena Berhalangan}

Upah ini diberikan oleh pengusaha kepada buruh yang tidak masuk kerja karena berhalangan akibat sakit atau haid,

\footnotetext{
${ }^{9}$ Abdul Khakim, Aspek Hukum Pengupahan Berdasarkan UU No. 13 Tahun 2003 (Bandung: PT. Citra Aditya Bakti, 2006), 23.
} 
sebagaimana diatur dalam Pasal 93 ayat (2) huruf a dan huruf $b$ UU No. 13 Tahun 2003.

4. Upah Tidak masuk Kerja Karena Melakukan Kegiatan Lain di Luar Pekerjaannya.

Upah ini diberikan oleh pengusaha kepada buruh yang tidak masuk kerja karena melakukan kegiatan lain di luar pekerjaannya, sebagimana diatur dalam Pasal 93 ayat (2) huruf c, huruf d, huruf e, huruf h, dan huruf i UU No. 13 Tahun 2003 tentang ketenagakerjaan.

5. Upah Karena Menjalankan Hak Waktu Istirahat Kerja.

Upah ini diberikan oleh pengusaha kepada buruh yang tidak masuk kerja karena ia melaksanakan hak waktu istirahat kerja sebagaimana diatur Pasal 93 ayat (2) huruf g UU No. 13 Tahun 2003.

6. Bentuk dan cara pembayaran upah sebagaimana telah dijelaskan pada pembahasan asas pengupahan di atas.

7. Struktur dan Skala Pengupahan yang Proposional.

Hal ini dimaksudkan sebagai pedoman penetapan upah sehingga terdapat kepastian upah setiap buruh, serta untuk mengurangi kesenjangan antar upah terendah dan tertinggi di perusahaan bersangkutan. Kenyataannya kebijakaan ini bersifat fakultatif sehingga pengusaha dapat melaksanakannya secara suka rela. Tidak ada sanksi hukum jika ia tidak melaksanakannya.

Pasal 92 ayat (1) UU No. 13 Tahun 2003 berbunyi:

"Pengusaha menyusun struktur dan skala upah dengan memperhatikan golongan, jabatan, masa kerja, pendidikan, dan kompetensi."

Dalam Pasal tersebut memang tidak ada kata wajib sehingga tidak mengikat untuk dilaksanakan. Kendatipun demikian, secara 
teknis pengaturan tentang struktur dan skala upah telah dikeluarkan Keputusn Menteri Tenaga Kerja dan Tranmigrasi No. KEP-49/MEN/IV/2004. minimal Kepmen tersebut menjadi alat bantu administrasi dan alat kebijakan pengupahan bagi perusahaan-perusahaan yang belum memiliki struktur dan skala upah yang standar.

\section{Upah Untuk Pembayaran Pesangon}

Di sinilah letak keunikan ketentuan upah dalam sistem hukum ketenaga kerjaan, tidak ada keseragaman definisi untuk semua kebutuhan. ada yang khusus untuk perhitungan pesangon, ada yang khusus untuk kebutuhan lain, seperti untuk perhitungan upah lembur, untuk pajak penghasilan dan sebagainya. ${ }^{10}$

9. Upah Untuk Perhitungan Pajak Penghasilan

Upah untuk perhitungan pajak penghasilan telah diatur dalam peraturan pemerintah No. 72 Tahun 2001 tentang Pajak Penghasilan yang diterima oleh pekerja sampai dengan sebesar upah minimum provinsi atau upah minimum Kabupaten/Kota. Pasal 1 menegaskan bahwa: "Pajak penghasilan atas penghasilan yang diterima pekerja sampai dengan sebesar upah minimum provinsi atau upah minimum kabupaten/kota ditanggung pemerintah".11

\section{Konsep Pengupahan Buruh Menurut Hukum Islam}

Pada dasarnya, upah (al-Ujrah $)^{12}$ adalah salah satu bentuk kompensasi yang diberikan oleh orang yang mempekerjakan kepada orang yang dipekerjakan berdasarkan aqad-aqad tertentu, dan secara khusus berhubungan erat dengan akad ijarah, suatu akad terhadap manfaat suatu benda atau jasa tertentu dengan

\footnotetext{
${ }^{10}$ Baca lebih lanjut perhitungan uang pesangon diatur dalam Pasal I 57 UU No. I3 Tahun 2003

"Ibid., 2 I

${ }^{12}$ Achmad Warson al-Munawwir, al-Munawwir, Kamus Arab-Indonesia (Yogjakarta: Pustaka Progresif. Cet XXV, 2002), 119
} 
jumlah imbalan ('iwadh) yang jelas..$^{13}$. Secara etimologi kata al-ujrah berarti al-Jaza (balasan) dan yang berarti al-thawab (pahala). ${ }^{14}$

Abdurrahman al-Maliki mengatakan bahwa upah adalah setiap harta yang diberikan sebagai kompensasi atas pekerjaan yang dikerjakan manusia, baik berupa uang maupun barang. ${ }^{15}$ Lanjutnya, bahwa kompensasi yang berupa uang jika dikaitkan dengan barang dinamakan harga (thaman), dan jika dikaitkan dengan tenaga dinamakan upah (al-ujrah).16

Menurut al-Qur'an bekerja itu adalah suatu kemuliaan dan kenikmatan tersendiri, yang kemudian dikaitkan dengan upah atau imbalan. ${ }^{17}$ Sedangkan dalam perspektif hadith dikatakan bahwa upah yang sifatnya materi (upah di dunia) mestilah terkait dengan keterjaminan dan ketercukupan pangan dan sandang buruh yang Menerima upah Perkataan: "harus diberinya makan seperti apa yang dimakannya (sendiri) dan memberi pakaian seperti apa yang dipakainya (sendiri)", bermakna bahwa upah yang diterima harus menjamin makan dan pakaian karyawan yang menerima upah. ${ }^{18}$

Oleh karena itu, dapat dikatakan bahwa upah adalah setiap uang atau barang yang diberikan kepada pekerja sebagai kompensasi atas jasa pekerjaan yang telah dikerjakannya dan bukan sekedar hadiah dari pemberi kerja kepada penerima kerja/buruh.

13 Fahr al-Din `Uthman bin Ali al-Hanafi ( selanjutnya disebut al- Zaila `i), Tabyin al-Haqaiq, vol.5 (Kairo: Matba `ah al-Kubra al-Amiriyah, 1315 H), 105 ; Abdullah al-Hijazi bin Ibrahim al-Shafi `i al-Azhari, Hashiyah al-Syarqawi ala Tuhfah al-Tullab, vol.2 (Beirut: Dar al-Marifah, tth), 8 ; Muhammad al-Khatib al- Sharbaini, Mughni al-Muhtaj, Vol. 2 (Kairo: Mustafa bab al-Halabi, 1985), 332 ; Mansur bin Yunus bin Idris al-Buhuti, Syarh Muntaha al-Iradat al-Musanna, Vol. 2 (Madinah: Maktabah al-Salafiyah, tth), 350.

I4al-Imam al-Majduddin al-Syafi' i, al-Qomus al-Muhit, (Kairo: Dar al-Salam,tth), 4.

${ }^{15}$ Abdurahman al-Maliki, Poltik Ekonomi Islam, Ter. Ibnu Sholeh ( Bangil: al-Izzah Cet I,200 I), 140.

${ }^{16}$ lbid., 14

${ }^{17}$ Lihat al-Qur`an, 4I (Fushshilat): 33 ; al-Qur`an, 36 (Yasin ): 35, al-Qur`an: ( al-Nahl): 97

${ }^{18}$ Lihat hadith riwayat abu Dzar dalam Shaleh, Mausu'ah al-Hadith al-Syarif Kutub al-Sittah Shahih Muslim Kitab al-Ayman bab 10 (Mesir: Maktab Dar al-Ilmi), 969 ; CD Maktabah Shamilah, Vol II. 
Adapun bentuk-bentuk upah dalam sistem ekonomi Islam terbagi menjadi dua macam, yaitu al-Ajr al-Musamma, dan al-Ajr alMithli. al-Ajr al-Musamma adalah upah yang sebutkan pada waktu akad dengan ada unsur kerelaan dari kedua belah pihak sedangkan al-Ajr al-al-Misthli adalah upah pengganti ketika dalam keadaan tidak diketahui atau ada paksaan atau penipuan. ${ }^{19}$ Kedua macam upah ini dalam pelaksanaannya terdapat ketentuanketentuan yang harus dipenuhi disaat berlangsungnya proses pengupahan. Di antaranya, seorang buruh haruslah dijelaskan bentuk kerjanya (job description), batas waktunya (timing), besar gaji/upahnya (take home pay), serta berapa besar tenaga /ketrampilan (skill) harus dikeluarkan. Gaji boleh diberikan secara tunai maupun tidak. Gaji boleh diberikan dalam bentuk uang, atau harta, maupun dengan jasa. ${ }^{20}$ Sebab, apapun yang bisa dikonversikan dengan harga, maka ia sah untuk dijadikan gaji, baik barang maupun jasa, dengan syarat harus jelas.

\section{Standarisasi Pengupahan Menurut Hukum Islam}

Pada dasarnya besarnya gaji ditentukan oleh jasa atau nilai kerja (produktivitas) itu sendiri, bukan ditentukan oleh tenaga (ain al-`Amal) yang dicurahkan oleh seorang pekerja, maupun harga produk yang dihasilkan oleh seorang pekerja. ${ }^{21}$ Besarnya gaji juga tidak ditentukan oleh kebijakan musta'jir (orang yang mempekerjakan) maupun ajir (pekerja). Untuk itu, walaupun dari sisi tenaga yang dicurahkan atau kerja yang dilakukan, seorang tukang batu atau penyapu jalan lebih besar dibandingkan dengan seorang dokter dan insiyur, namun demikian, upah seorang tukang batu tidak sebesar seorang dokter. Ini bisa dimengerti karena kegunaan kerja atau jasa yang diberikan oleh dokter lebih besar dibandingkan dengan seorang tukang batu.

\footnotetext{
${ }^{19}$ Rafiq Yunus al-Mashri, Ushul al-lqtisad al-Islami (Damaskus: Dar al-Qalam, 1993), 202.

${ }^{20}$ Muhammad Abdul Mun'im, Ushul al-lqtisad al-Islami (Kairo: Dar al-Fath, 1996), 325; Rafiq Yunus, Ushul, 194-195.

${ }^{21}$ Ibid., 92.
} 
Ada banyak teori yang menjelaskan besaran dan jenis upah yang mesti diterima buruh. ${ }^{22}$ Antara lain adalah;

1. Teori Subsistensi yang digunakan untuk pekerja yang tidak mempunyai keterampilan khusus. Upah, menurut teori ini, didasarkan pada tingkat subsistensi sesuai tingkat kebutuhan mendasar;

2. Teori Dana Upah. Menurut teori ini, upah pekerja adalah bagian dari modal untuk berproduksi. Besaran upah pekerja akan selalu didasarkan pada penambahan modal atau pengurangan jumlah pekerja;

3. Teori Marginal Productivity. Menurut teori ini, upah tenaga kerja didasarkan pada permintaan dan penawaran tenaga kerja. Pengusaha akan menambah upah pekerja sampai batas pertambahan produktivitas marjinal minimal sama dengan upah yang diberikan pada mereka.

4. Teori Bargaining. Teori ini mengandaikan ada batas minimal dan maksimal upah. Upah yang ada merupakan hasil persetujuan kedua belah pihak;

5. Teori Daya Beli. Teori ini mendasarkan permintaan pasar atas barang dengan upah. Agar barang terbeli, maka upah harus tinggi. Jika upah rendah, maka daya beli tidak ada, dan barang tidak laku. Jika hal ini dibiarkan, maka akan terjadi pengangguran besar-besaran;

6. Teori upah hukum alam. Teori ini menyatakan bahwa upah ditetapkan atas dasar biaya yang diperlukan untuk memelihara atau memulihkan tenaga buruh yang telah dipakai untuk berproduksi..$^{23}$

Konsepsi Islam tentang upah sesungguhnya hampir sama dengan Teori Marginal Productivity dan Teori Bargaining. Sebagaimana penjelasan di atas, teori marginal productivity

\footnotetext{
22 Indaryani, dkk, "Hasil penelitian penetapan upah minimal di Kabupaten Kudus Jateng" , ( Kudus: Kantor Tenaga Kerja dan Transmigrasi bekerja sama dengan litbang UMK, 2002)

${ }^{23}$ Baca lebih lanjut: Mannan, M.A. Islamic Economy: Theory and Practice (England: Edward Arnold Limited, 1993), 70 ; Budiono, Teori Eknomi Mikro (Yogyakarta: BPFE, 1998)
} 
menyatakan bahwa upah tenaga kerja didasarkan pada permintaan dan penawaran tenaga kerja. Sedangkan teori Bargaining mengandaikan ada batas minimal dan maksimal upah. Upah yang ada merupakan hasil persetujuan kedua belah pihak.

Dengan cara ini, maka upah dapat ditentukan secara transparan, seksama, adil, dan tidak menindas pihak manapun. Setiap pihak mendapat bagian yang sah dari hasil usahanya, tanpa menzalimi pihak yang lain, sebagaimana firman Allah swt QS 53 (al-Najm), 39:

"Dan bahwasanya seorang manusia tiada memperoleh selain apa yang telah diusahakannya. Dan bahwasanya usahanya itu kelak akan diperlihatkan (kepadanya). Kemudian akan diberi balasan kepadanya dengan balasan yang paling sempurna"

Masuknya komponen biaya hidup dalam upah, tidak sematamata pertimbangan produktivitas kerja, memang masalah tersendiri jika majikan memetaforakan tenaga kerja sebagai mesin. Akan tetapi, dengan pertimbangan surplus value (nilai lebih) dan kelayakan bagi kemanusiaan, hal tersebut bisa diterima.

Dalam konteks inilah Islam bisa menerima kehadiran Upah Minimum. Allah berfirman QS, 20 ( Taha): 119-120 :

"Sesungguhnya kamu tidak akan kelaparan di dalamnya dan tidak akan telanjang. dan sesungguhnya kamu tidak akan merasa dahaga dan tidak (pula) akan ditimpa panas matahari di dalamnya".

Nabi juga menyatakan dalam hadith riwayat Ahmad (artinya):

"Saya mendengar Nabi bersabda: Barang siapa mengangkat pekerja, jika ia tidak mempunyai rumah harus dibikinkan rumah; jika belum menikah harus dinikahkan; jika tidak mempunyai pembantu harus dicarikan pembantu; jika tidak mempunyai kendaraan harus diberikan kendaraan. Jika majikan tidak memberikan hal tersebut, ia adalah pembunuh" 
Dalam diskursus ekonomi Islam, kebutuhan manusia dibagi menjadi tiga tingkatan, yaitu; daruriyat, hajiyat dan tahsiniyat. Daruriyat merupakan segala sesuatu yang tidak dapat ditinggalkan dalam kehidupan keagamaan dan keduniaan manusia (maqasid asliyah), sesuatu yang wajib adanya dan menjadi pokok kebutuhan hidup untuk menegakkan kemaslahatan manusia yang berpangkal kepada al-Daruriyat al-Khams (lima macam kepentingan vital), yaitu pemeliharaan terhadap agama (hifz al-din), jiwa (hifz al-nafs), akal (hifz al-`aql), keturunan (hifz al-nasl), dan harta (hifz al-mal). Hajiyat bersifat menyempurnakan dan mendukung kebutuhan Daruriyat, ia berkenaan dengan sesuatu yang dibutuhkan manusia dalam menghindari kesempitan dan menolak kesulitan. Tahsiniyat menyempurnakan kebutuhan Daruriyat dan Hajiyat, ia berkenaan dengan hal-hal yang menjadi tuntutan dari martabat diri dan akhlak yang mulia atau yang ditujukan untuk mendapatkan adat istiadat yang baik. ${ }^{24}$

Dalam sebagian hadith dan nash fikih, dipahami bahwa 'Amil khususnya pada sektor umum ditanggung oleh wali al-amri sesuai standar kelayakan. ${ }^{25}$ Imam Juwaini, sebagaimana dikutip oleh Rafiq al-Mashri cenderung berpendapat bahwa pemerintah hendaknya mencukupi kebutuhan rakyatnya. Mereka harus dicukupi kebutuhan dasar mereka, agar mereka tetap semangat berjuang dijalan Islam, seperti tentara, para hakim, fuqaha dan qadi. Mencukupi ini bisa melalui upah kerja atau melalui subsidi/jaminan sosial (misalnya, zakat) atau dari kedua-duanya bersamaan. ${ }^{26}$

Data sejarah menunjukkan bahwa upah minimum di masa Rasul (tahun 5 H) adalah 200 dirham, sedang upah maksimumnya

\footnotetext{
${ }^{24}$ Al-Shatibi, al-Muwafaqat fi Ushul al-Ahkam, vol.2 (Beirut: Dar al-Fikr, I34IH), 4 ; (Wahbah alZuhali, Konsep Darurat dalam Hukum Islam: Studi banding dengan Hukum Positif, Terj.Jakarta:Gaya Media Pratama, 1997), 5I; Abdullah bin Hasan al-Jabiri, al-Mushkilah alIqtisadiyah (Kairo; Dar al-Fath, tth), 125 ; Mumammad Abdul Mun`im, Usul al-Iqtisad al-Islami (Kairo: Dar al-Fath, 1996), 4I-52.

${ }^{25}$ Lihat Abu Ubaid, al-Amwal, Tahqiq Muhammad Khalil Haras (Beirut: dar al-Fikr, 1975)

${ }^{26}$ Rafiq Yunus al-Mashri, Ushul al-lqtisad, 205.
} 
adalah 2000 dirham, dengan perbandingan 1:10. Seiring dengan perkembangan perekonomian Madinah saat itu, upah minimumnya menjadi 300 dirham dan upah maksimumnya 3000 dirham. ${ }^{27}$ Islam tetap mengakui perbedaan upah karena faktor perbedaan skill dan pengalaman kerja.

Meskipun pekerjaan itu merupakan salah satu unsur produksi, tetapi dalam memperkirakan upah hendaknya tidak dikaitkan dengan harga-harga barang atau biaya produksi itu sendiri, karena upah dan harga itu sendiri merupakan dua permasalahan yang berbeda dan berangkat dari permaslahan yang berbeda pula, di mana harga itu berangkat dari adanya jual beli, sedangkan upah itu berangkat dari ijarah, dan juga karena upah itu merupakan kompensasi dari jasa pekerjaan yang disesuaikan dengan nilai kegunaannya selama upah tersebut ditentukan di antara keduanya. Di samping itu, menentukan upah berdasarkan harga atau sebaliknya akan mengakibatkan seorang pekerja bisa mengendalikan seorang pemberi kerja dengan menaikkan atau menurunkan upah seenaknya sendiri dengan alasan turun dan naiknya harga. Di lain pihak, tidak bisa diklaim bahwa pemaksaan seorang pemberi kerja di saat memberikan upah yang telah ditentukan dalam kondisi menurunnya harga barang yang dihasilkan, akan menyebabkan seorang pemberi kerja pailit. Sebab akan mneyebabkan keluarnya seorang pekerja ketika barang di pasar secara keseluruhan merosot. ${ }^{28}$

Sementara, konsep upah menurut Ibnu Taimiyah bahwa konsep adil adalah bahwa penggunaan dan implikasi upah sama halnya dengan konsep harga yang adil..$^{29}$ Oleh karena itu masalah penentuan upah tidak banyak berbeda dengan pematokan harga. Hanya saja istilah yang sering digunakan oleh Ibnu Taimiyah dalam menjelaskan persoalan ini dalah tas 'ir fi al-`Amal yang

\footnotetext{
${ }^{27}$ Philip K. Hitti, History of The Arabs (London: The Macmillan Press Ltd, 1970)

${ }^{28}$ Taqiyuddin al-Nabhani, "Membangun sistem ekonomi alternatif, 107.

${ }^{29}$ Adiwarman Azwar Karim, Sejarah perekonomian Islam (Jakarta: PT.Raja Grapindo Persada, 2004), 34I.
} 
secara literal bermakna pematokan nilai harga atas suatu jenis pekerjaan, dan dengan menggunakan istilah al-Ujrah al-Misli (upah yang setara). Jadi, tas`ir fi al-`Amal (tahdid al-Ujur) itu adil jaiz bahkan wajib hukumnya. ${ }^{30}$ Ibn Qayyim menyebutkan bahwa tas 'ir fi al-'Amal tidak terjadi pada masa Rasulullah saw di Madinah. Karena budaya buruh belum ada dalam masyarakat Madinah. mereka tidak menumbuk dan membuat roti dengan upah, tetapi mereka membeli biji gandum lalu menumbuk dan membuat roti di rumah sendiri. ${ }^{31}$

Tujuan dasar dari upah yang adil (sepadan) untuk melindungi kepentingan pekerja dan majikan serta melindungi mereka dari saling mengeksploitasi dalam setia transaksi bisnis. Sehubungan dengan hal ini Ibn Taimiyah dalam kitab Majmu`-nya menyatakan, (artinya) :

"Apabila seorang manjikan (pemberi jasa) memperkerjakan seorang pekerja secara curang (zalim) dengan membanyar upah pada tingkat lebih rendah dari upah yang adil, yang secara normal orang lain pun akan menolak jika dibayar dengan tarif sebesar itu, maka pekerja itu berhak meminta dibayar dengan upah yang adil (sepadan). ${ }^{32}$

"Jika seorang pekerja tidak bisa menyelesaikan pekerjaannya, maka ia tidak berhak memperoleh upahnya secara utuh. Ia hanya berhak memperoleh upahnya sesuai dengan hasil pekerjaannya. ${ }^{33}$

Pada dasarnya buruh berhak mendapat kompensasi atas jerih payahnya baik berupa upah (ujrah) tertentu atau prosentase tertentu dari produksi dan atau laba (ribh) bersih perusahaan. Untuk model perolehan jenis kompensasi yang kedua tersebut

\footnotetext{
${ }^{30}$ Rafiq Yunus al-Mashri, Ushul al-lqtisad, 203.

${ }^{31}$ Ibn Qayyim, al-Turuq al-Hukmiyyah fi al-Siyasah-al-Shariyyah (Beirut: Dar al-Kutub al-Ilmiyah, tth), 252 ; Ibn Taimiyyah, Majmu ' Fatawa Ibn Taimiyyah, Vol. 28 ( Saudi Arabia: Tab`ah Sa 'udiyyah, 1398 H), 88

${ }^{32}$ Ibn Taimiyah, Majmu ' Fatawa Ibnu Taimiyah Vol. 30 ( Riyad: Matba` al-Riyad, I38I H), 163.

$33 \mathrm{lbid}, 183$.
} 
dapat diaplikasikan konsep mudarabah,34 yaitu akad kerja sama antara pemilik modal (pengusaha) dengan pekerja (amil) untuk melaksanakan sebuah pekerjaan dengan perolehan prosentase keuntungan tertentu dari laba. Tugas pekerja adalah mengembangkan modal yang dimiliki pengusaha dan meningkatkan produktivitas kerja sehingga mendatangkan laba yang kemudian dibagi berdasarkan prosentase yang disepakati bersama pemilik modal. ${ }^{35}$

Kemudian, Islam juga menawarkan kombinasi konsep ijarah dengan Shirkah inan. Sebagaimana diketahui, bahwa Shirkah 'Inan adalah kontrak kerja sama antara dua orang atau lebih untuk melaksanakan sebuah pekerjaan. Setiap pihak memberikan suatu porsi dari keseluruhan dana, dan juga berpartisipasi dalam kerja. ${ }^{36}$ Kedua belah pihak berbagi dalam untung maupun rugi (profit-loss sharing) sesuai dengan kesepakatan yang mereka capai. ${ }^{37}$

Memang dalam kitab-kitab fikih tidak disebutkan bolehnya mengadakan transaksi secara bersama-sama antara ijarah dan shirkah bahkan terdapat larangan tentang hal itu karena 'amil menjadi ajir dan sharik pada waktu bersamaan padahal keduanya merupakan akad yang berbeda. Tetapi, menurut Rafiq Yunus alMashri bahwa apa yang dibolehkan dalam pengupahan (ijarah), maka boleh juga shirkah dan boleh mengkombinasikan keduanya. ${ }^{38}$

Aplikasi teori shirkah ini dapat menggunakan gainsharing approach sebagaimana telah dilakukan oleh Manajemen Sumber Daya Modern. Gainsharing adalah pendekatan kompensasi yang berhubungan dengan outcome tertentu. Sistem ini di set up sebagai bentuk berbagi keuntungan dengan pekerja atas performa dan

\footnotetext{
${ }^{34}$ Menurut Hanabilah, akad mudarabah dimasukkan ke dalam bab Shirkah, sementara Jumhur Fuqaha memasukkannya ke dalam bab ijarah. Baca selengkapnya Muhammad salah Muhammad sawi, Mushkilah al-Istithmar fi al-Bunuk al-Islami (Dar al-Wafa, 1990), 24

${ }^{35}$ Muhammad Abdul Mun`im, Ushul al-lqtisad, 326.

${ }^{36}$ Muhammad salah, Mushkilah al-Istithmar, 24 ; Ibnu Quddamah, al-Mughni, Vol.5, 124 ; Ibn Rusyd, Bidayah al-Mutahid, vol.2, 25I.

${ }^{37}$ Nazih Hammad, Mu 'jam al-Mustalahah al-lqtisadiyah fi Lughah al-Fuqaha' (Virginia: IIIT, 1993), 168.

${ }^{38}$ Rafiq Yunus al-Masri Ushul al-lqtisad, 199.
} 
produktvitas mereka dalam menghasilkan peningkatan laba dalam perusahaan.

1. Employee ownership

Employee ownership adalah pendekatan gainsharing bagi pekerja untuk memiliki perusahaan. Beberapa perusahaan memperbolehkan pekerja membeli sahamnya sebagai andil perusahaan. Hasilnya adalah partisipasi pekerja dalam memiliki bagian-bagian perusahaan. Pendekatan revolusioner ini salah satunya diwujudkan dengan rencana kepemilikan saham pekerja, atau ESOP (Employee Stock Ownership Plan). Sekalipun employee ownership dilakukan dengan berbagai cara, namun semua berarti pekerja membeli saham perusahaan.

\section{Production sharing plans}

Production sharing plans adalah rencana pembagian produksi dengan pekerja dengan memberikan bonus ketika melebihi tingkat output yang direncanakan. Rencana ini cenderung menjadi jangka pendek dan berhubungan dengan tujuan produksi yang spesifik.

\section{Profit-Sharing Plans}

Profit-sharing plans adalah sistem membagi keuntungan perusahaan dengan para pekerja. Profit-sharing dipilih karena keuntungan tidak selalu berhubungan dengan performa pekerja. Sebuah resesi atau kompetisi baru bisa berpengaruh secara signifikan. Beberapa perusahaan kemudian mengantisipasinya dengan mengurangi insentif untuk kemudian mengalokasikannya pada pembagian profit pekerja. Ketika langkah reinforcement (penguatan) ini berjalan dengan baik, maka akan menimbulkan pengaruh yang dramatis pada organisasi, melahirkan kepercayaan baru dan memunculkan perasaan senasib-sepenanggungan di antara para pekerja dan menajemen. ${ }^{39}$

Dengan gainsharing system di atas, maka relasi buruh majikan

\footnotetext{
${ }^{39}$ Abdul Jalil, Hubungan Industrial di Indonesia: Prespektif Ekonomi Islam. www. dipertais.co.id.
} 
adalah hubungan kemitraan (patership relation ) untuk mencari rezeki Allah yang halal. Di samping itu, mereka juga masih menerima upah harian yang besaran dan regulasinya menggunakan model Ijarah, yang secara teoritik hampir sama dengan Teori Marginal Productivity dan Teori Bargaining.

\section{Politik Negara dalam Pengupahan Buruh}

Dalam koteks Negara Indonesia, kesejahteraan para pekerja tidak begitu jelas mengenai siapa pihak yang paling bertanggung jawab. Hal ini sering menjadi sumber problema perburuhan. Saat ini terdapat kecenderungan pemahaman bahwa kesejahteraan pekerja adalah tanggung jawab pengusaha, yaitu mencukupi KHM (Kebutuhan Hidup Minimum). Negara dalam hal ini seolah-olah lepas tangan sama sekali dari kewajiban di atas. Tindakan seperti ini sudah tentu bertentangan dengan tata cara Islam. Dalam Islam, negara lah yang mengatur dan mengurus kepentingan rakyatnya. Jaminan kesehatan, hidup layak, pendidikan dan kebutuhan pokok lainnya (daruriyat) seharusnya menjadi tanggung jawab negara. Karena negaralah yang bertugas memelihara kemaslahatan umum (maslahah al-`ammah). Negara harus menjamin seluruh fasilitas kesehatan dan pendidikan yang memadai sehingga dapat dinikmati oleh seluruh warga negaratidak hanya para buruh. Dalam konteks pengupahan negara harus bertanggung jawab untuk menciptakan upah adil minimal bisa memenuhi kebutuhan pokok buruh dan mengawasi (hisbah) pelaksanaan kebijakan tersebut di setiap perusahaan. ${ }^{40}$

Menurut Baqir Sharief Qorashi bahwa, pihak-pihak yang dapat menentukan upah adalah:

a) Buruh dan pemilik usaha; keduanya bersepakat dalam menentukannya.

b) Serikat buruh. Ini dikarenakan mereka berkompeten dalam menentukan upah buruh bersama pemilik usaha, dengan syarat

${ }^{40}$ Ali Ahmad al-Salus, al-lqtisad al-Islami wa al-Qadaya al-Fiqhiyyah al-Mu 'asarah, vol.I (Dauhah: Dar al-Thaqafah, 1998), 86. 
buruh memberikan kewenangan kepada mereka untuk melakukannya.

c) Negara. Namun disyaratkan bahwa dalam interverensinya, negara tidak menghilangkan hak-hak buruh maupun hak-hak pemilik usaha. Apabila upah telah ditentukan, maka buruh memiliki kemerdekaan penuh untuk menerima atau menolaknya tanpa adanya unsur paksaan. ${ }^{41}$

Yusuf Qardawi memandang bahwa dalam masalah penentuan upah kaum buruh harus ada interverensi pemerintah atau negara. Tugas pemerintah menurut Islam tidak hanya terbatas pada kewajiban menjaga keamanan dalam negeri, akan tetapi tugas-tugasnya harus menyeluruh yang bertujuan untuk menghapus kezaliman, menegakkan jaminan dan keadilan bagi semua masyarakat, dan mewujudkan sikap saling tolong menolong, sebagaimana dasar-dasar shariah yang dapat dijadikan sebagai dalil, diantaranya:

a) Dalam sistem Islam, tanggung jawab berada di tangan seorang Imam secara mutlak. ${ }^{42}$ Sebagaimana sabda Nabi saw: " Imam (kepala Negara) itu bagaikan pengembala alias pemimpin dan dia akan dimintai pertanggungjawaban atas rakyat yang dia pimpin".(HR.Ahmad, Shaikhani dan Abu Dawud).

b) Salah satu tujuan penetapan hukum Islam adalah untuk menegakkan keadilan di dalam kehidupan umat manusia, dan Islam sendiri sangat mendukung setiap tingkah laku atau tindakan yang bertujuan untuk menegakkan dan meniadakan kezaliman. ${ }^{43}$ Sebagaimana disebutkan dalam al-Quran Surat alNisa 58 yang artinya :

"Sesungguhnya Allah mendengar lagi Maha melihat.menyuruh kamu menyampaikan amanat kepada yang berhak menerimanya, dan (menyuruh kamu) apabila menetapkan hukum di antara manusia

${ }^{41}$ Baqir Sharief Qorashi, Keringat buruh, hak dan peran pekerja dalam Islam (Jakarta: PT. al-Huda, 2007) , 25I.

${ }^{42}$ Yusuf Qardhawi, Fatawa Mutakhir. Terj al-Hamid al-Husaini (Jakarta: Yayasan al-Hamidy Cet III, 1996), 735.

${ }^{43}$ lbid., 736. 
supaya kamu menetapkan dengan adil. Sesungguhnya Allah memberi pengajaran yang sebaik-baiknya kepadamu. Sesungguhnya Allah adalah Maha"

c) Shariah Islam berusaha mencegah terjadinya perbuatan yang mengakibatkan kemadharatan dan tindakan merugikan (dhirar)orang lain. ${ }^{44}$

d) Hukum Islam membuka pintu seluasnya bagi negara untuk menentukan kebijakan dalam upaya mewujudkan apa yang dipandangnya sebagai kemaslahatan umum, atau mengambil tindakan untuk mencegah dan menanggulangi gejala-gejala tertentu yang tidak sehat, asalkan tidak bertentangan dengan nas-nas yang "muhkam ", yakni firman-firman Allah dalam alQur'an dan hadith-hadith sahih, dan tidak pula bertentangan dengan kaidah hukum yang tetap.

\section{Kritik Atas Politik Pengupahan Buruh di Indonesia}

Sampai kini, persoalan pengupahan ibarat lingkaran setan bagi industri, buruh, dan pemerintah. Di satu sisi, jika pemerintah tidak menaikkan upah, kondisi buruh semakin tertekan dan ini dapat menciptakan kerawanan sosial yang jauh lebih hebat dari sekedar orang hidup di bawah garis kemiskinan. Di satu sisi, dengan menaikkan upah buruh berarti hilangnya daya saing, karena keunggulan kompetitif yang dimiliki industri manufaktur nasional bukan terletak pada produk dan efisiensi infrastruktur serta birokrasi, tapi terletak pada upah buruh yang murah.

Menghadapi kondisi dilematis ini, posisi pemerintah lebih condong kepada kepentingan pengusaha dan kurang berani menaikkan upah pada tingkat yang wajar untuk memberi hidup sedikit lebih manusiawi kepada para buruh. Ironisnya, dengan kondisi yang serba marginal itu, sering pengusaha menuntut produktivitas yang tinggi kepada buruh sebelum menaikkan upah minimal yang diminta, tanpa mau mendukung langkah yang

44 lbid., 737. 
dapat memberikan nilai tambah ke buruh, seperti pendidikan dan latihan kerja. ${ }^{45}$

Sudah waktunya upah ditentukan berdasarkan KHM (Kebutuhan Hidup Minimum) yang tolok ukur dan komponennya didasarkan pada surve terbaru pengeluaran riil buruh. Tolok ukur KHM yang ada tidak cocok dengan realitas pengeluaran buruh baik mengenai kualitas maupun kuantitas barang. Kenaikan upah minimum jangan hanya menaikkan nilai secara nominalnya saja, melainkan juga nilai riilnya. UMR yang selama ini ditetapkan pemerintah sudah tak memadai. Sudah waktunya landasan yang digunakan adalah KHL (Kebutuhan Hidup Layak), sehingga upah buruh sesuai dengan amanat UUD 45, yaitu upah yang layak bagi kemanusiaan. Hingga kini besarnya upah minimum belum pernah mencapai nilai kebutuhan hidup layak (KHL). Kenaikan rata-rata 15 persen dari UMR belum menunjukkan kemajuan, karena standarnya masih KFM (Kebutuhan Fisik Mininum) sementara tingkat inflasi mencapai sekitar 10 persen. Kenaikan upah secara makro menyebabkan naiknya daya beli masyarakat. Namun, nyaris kenaikan upah selalu diikuti oleh kenaikan inflasi (demand side) sehingga daya beli riil masyarakat tidak mengalami perubahan.

\section{Penutup}

Salah satu problem yang langsung menyentuh kaum buruh adalah rendahnya atau tidak sesuainya pendapatan (gaji) yang diperoleh dengan tuntutan untuk memenuhi kebutuhan hidupnya beserta tanggungannya. Sementara itu dalam sistem ekonomi Kapitalis, rendahnya gaji buruh justru menjadi penarik bagi para investor asing termasuk pemerintah untuk kepentingan peningkatan pendapatannya sendiri (bukan rakyat). Untuk membantu mengatasi problem gaji, pemerintah tiap tahun membuat 'batas minimal gaji' yang harus dibayarkan oleh

\footnotetext{
${ }^{45}$ Eggi Sudjana, Buruh Menggugat, Perspektif Islam (Jakarta: Pustaka Sinar Harapan, 2002), 88.
} 
perusahaan kepada pekerjanya, yang kemudian dikenal dengan istilah UMR atau UMK. Nilai UMR dan UMK ini biasanya dihitung bersama berbagai pihak yang merujuk kepada Kebutuhan Fisik Minimum Keluarga (KFM), Kebutuhan Hidup Minimum (KHM) atau kondisi lain di daerah yang bersangkutan.

Di dalam Islam jelas akan berbeda penanganannya. Profesionalisme kerja sangatlah dihargai oleh Islam. Sehingga upah seorang pekerja benar-benar didasari pada keahlian dan manfaat tenaga yang bisa diberikan oleh si pekerja itu. Karena pada dasarnya besarnya gaji ditentukan oleh jasa atau nilai kerja (produktivitas) itu sendiri, bukan ditentukan oleh tenaga (ain al‘mal) yang dicurahkan oleh seorang pekerja, maupun harga produk yang dihasilkan oleh seorang pekerja. ${ }^{46}$ Lebih dari itu, besaran upah hendaknya juga dikaitkan dengan hak dasar untuk hidup (hifz al-nafs) secara layak, bukan semata-mata oleh sejauhmana produktivitas mereka dalam segala level buruh. Dengan demikian, dalam Islam, upah yang layak bukanlah semata-mata konsesi buruh-majikan, tetapi merupakan hak asasi yang dapat dipaksakan oleh kekuasaan negara. Majikan harus memberikan upah minimum yang bisa menutupi keperluan dasar hidup (daruriyat) yang meliputi makanan, pakaian, tempat tinggal, kesehatan, sarana komunikasi dan transportasi, jaminan keamanan dan sebagainya. Upah riil di masyarakat Muslim idealnya mencapai level sejahtera sehingga mereka dapat memenuhi kebutuhan pokok mereka dan keluarganya. Sangat ironis bila buruh diberi upah yang rendah sementara ia dipaksa kerja keras 10-14 jam tiap hari. ${ }^{47}$

\footnotetext{
${ }^{46}$ Taqituddin al-Nabhany, Ekomoni Islam, 92.

${ }^{47}$ Umer Chapra, Islam and Economic development, 66.
} 


\section{Daftar Rujukan}

Akram. An Introduction to Islamic Economics. Pakistan: IITH, 1994.

Ali, Fahr al-Din 'Uthman bin. Tabyin al-Haqaiq. Vol. 5, Kairo: Matba'ah al-Kubra al-Amiriyah, $1315 \mathrm{H}$.

Asqalani (al-), Ibn Hajar. Bulugh al-Maram. Beirut: Darul Fikr, 1994. Azhari (al-), Abdullah al-Hijazi bin Ibrahim al-Shafi i. Hashiyah alSyarqawi ala Tuhfah al-Tullab. vol.2, Beirut: Dar al-Marifah, tth.

Azwar Karim, Adiwarman. Sejarah Perekonomian Islam. Jakarta:

PT.Raja Grapindo Persada, 2004.

Budiono. Teori Eknomi Mikro. Yogyakarta: BPFE, 1998.

Buhuti (al-), Mansur bin Yunus bin Idris. Syarh Muntaha al-Iradat alMusanna. Vol. 2, Madinah: Maktabah al-Salafiyah, tth.

Chapra, M. Umer. Islam and economic development. IIIT: Islamabad, 1993.

Fazlurrahman (al-). Doktrin ekonomi Islam. Jilid II, terj. Soeroyo dan

Nastangin, Yogyakarta: Dana Bakti Wakaf, 1995.

Fronm, Erich. Konsep manusia menurut max, terj. Agus Prihantara, Yogyakarta: Pustaka Pelajar, 2002.

Hammad, Nazih. Mu'jam al-Mustalahah al-Iqtisadiyah fi Lughah alFuqaha`. Virginia: IIIT, 1993.

Hitti, Philip K. History of The Arabs. London: The Macmillan Press Ltd, 1970.

Ibn Qayyim. al-Turuq al-Hukmiyyah fi al-Siyasah-al-Shariyyah. Beirut: Dar al-Kutub al-Ilmiyah, tth.

Ibn Rusyd. Bidayah al-Mujtahid wa Nihayah al-Mugtasid, Vol.2, Kairo: Maktabah al-Tijariyah al-Kubra, tth.

Ibn Taimiyah. Majmu' Fatawa Ibnu Taimiyah, Vol. 30, Riyad: Matba` al-Riyad, $1381 \mathrm{H}$.

Ibn Taimiyyah. Majmu' Fatawa Ibn Taimiyyah, Vol. 28, Saudi Arabia: Tab`ah Sa`udiyyah,1398 H.

Ibnu Quddamah. al-Mughni. Vol. 5, Beirut: Dar al-Kitab al-Arabi, tth. 
Indaryani, dkk, "Hasil penelitian penetapan upah minimal di Kabupaten Kudus Jateng",

Islahi, AA. Konsep Ekonomi Ibn Taimiyah, terj. Ansori Thayib, Surabaya: PT.Bina Ilmu, 1997.

Jabiri (al-), Abdullah bin Hasan. al-Mushkilah al-Iqtisadiyah. Kairo; Dar al-Fath, tth.

Jalil, Abdul. Hubungan Industrial di Indonesia: Prespektif Ekonomi Islam. dalam www. dipertais.co.id.

Khakim, Abdul. Aspek Hukum Pengupahan Berdasarkan UU No. 13 Tahun 2003. Bandung: PT. Citra Aditya Bakti, 2006.

Kudus: Kantor Tenaga Kerja dan Transmigrasi bekerja sama dengan litbang UMK, 2002)

Labiba, Umnia. Wahyu Pembebasan, Relasi Buruh -Majikan, Yogyakarta: PT.Pustaka Alif, 2004.

Maliki (al-), Abdurahman. Poltik Ekonomi Islam, terj. Ibnu Sholeh, Bangil: al-Izzah Cet I, 2001.

Mannan, M.A. Islamic Economy: Theory and Practice. England: Edward Arnold Limited, 1993.

Mashri (al-), Rafiq Yunus. Ushul al-Iqtisad al-Islami. Damaskus: Dar al-Qalam, 1993.

Muhammad, Abdul Mun im. Ushul al-Iqtisad al-Islami. Kairo: Dar al-Fath, 1996.

Munawwir (al-), Achmad Warson. al-Munawwir, Kamus ArabIndonesia. Yogjakarta: Pustaka Progresif. Cet XXV, 2002.

Qardhawi, Yusuf. Fatawa Mutakhir, terj. al-Hamid al-Husaini, Jakarta: Yayasan al-Hamidy, Cet III, 1996.

Qorash, Baqir Sharief. Keringat Buruh, Hak dan Peran Pekerja dalam Islam. Jakarta: PT. al-Huda, 2007.

Ruky Ruky, Ahmad S. Manajemen Penggajian dan Pengupahan Karyawan Perusahaan. Jakarta: Pustaka Utama Gramedia, 2001.

Salih, Suad Ibrahim. Mabadi al-Nidam al-Islami. Kairo: Dar al-Diya', 1997.

Salus (al-), Ali Ahmad. al-Iqtisad al-Islami wa al-Qadaya al-Fighiyyah al-Mu asarah. Vol.1, Dauhah: Dar al-Thaqafah, 1998. 
Sawi, Muhammad Salah Muhammad. Mushkilah al-Istithmar fi alBunuk al-Islami. Dar al-Wafa, 1990.

Semaoen. Penuntun Kaum Buruh. Yogyakarya: Jendela, 2000.

Shaleh. Mausu'ah al-Hadith al-Syarif Kutub al-Sittah Shahih Muslim Kitab al-Ayman Bab 10. Mesir: Maktab Dar al-Ilmi.

Sharbaini (al-), Muhammad al-Khatib. Mughni al-Muhtaj. Vol. 2, Kairo: Mustafa bab al- Halabi, 1985.

Shatibi (al-). al-Muwafaqat fi Ushul al-Ahkam. Vol. 2, Beirut: Dar alFikr, $1341 \mathrm{H}$.

Soepomo, Imam. Hukum Perbudakan Bidang Hubungan Kerja. Jakarta: Djambatan, 1987.

Sudjana, Eggi. Bayarlah sebelum Keringatnya Mengering. Jakarta: PPMI, 2000.

-------- Buruh Menggugat, Perspektif Islam. Jakarta: Pustaka Sinar Harapan, 2002.

Susetiawan. Konflik Sosial: Kajian Sosiologis Relasi Buruh Perusahaan dan Negara di Indonesia. Yogyakarta: Pustaka Pelajar, 2000.

Sutanto. Prospektif Tenaga Kerja dalam Hubungan Industrial Sesuai Dengan UU No.13 tahun 2003. Makalah disampaikan dalam kongres sarjana ekonomi Indonesia XV, Batu, Malang 13-15 Juli 2003

Syafi'i (al-), al-Imam al-Majduddin. al-Qomus al-Muhit. Kairo: Dar al-Salam, tth.

Ubaid, Abu. al-Amwal. Tahqiq Muhammad Khalil Haras, Beirut: dar al-Fikr, 1975.

Widarti, Agung. "Buruh di Sektor Industri dalam Perdagangan Global." Makalah saresehan Nasional dan konggres Formasi, Semarang 27 Maret 1997.

Zuhaili, Wahbah. Konsep Darurat dalam Hukum Islam: Studi banding dengan Hukum Positif, terj. Jakarta: Gaya Media Pratama, 1997.

-------. Al-Figh al-Islami Wa Adillatuh, Vol.5, Beirut: Dar el-Fikr, 2000. 